\title{
Octreotide Use in Neonates: A Case Series
}

\author{
Syed Ahmed Zaki ${ }^{1} \cdot$ Mohan B. Krishnamurthy ${ }^{1} \cdot$ Atul Malhotra $^{2}$
}

Published online: 15 June 2018

(C) The Author(s) 2018

\begin{abstract}
Background and Objective Octreotide is a somatostatin analogue and has been used off-label for a variety of conditions. There are no specific guidelines for the use of octreotide in neonates and its safety and efficacy have not been systematically evaluated. The objective of this study is to present our experience of using octreotide therapy in neonates.

Methods This is a retrospective study of neonates who received octreotide therapy during their hospital stay over a 15 years period (2003-2017) in a tertiary neonatal centre. The demographic details and indications of octreotide therapy including time of initiation, route, dose, duration and adverse effects of therapy were noted. The clinical course following octreotide administration was also analysed.

Results Eleven neonates received octreotide therapy during the study period, of which nine had chylothorax and two had chylous ascites. Resolution of the chylous effusion with octreotide therapy was achieved in 4 out of 11 (36.3\%) of the cases. The median duration of octreotide therapy in cases with successful resolution was 17.5 days. With the exception of minor side effects such as hyperglycaemia, none of the patients had any significant side effects that required discontinuation of therapy.

Conclusion Octreotide was used safely as an adjunctive therapy for the treatment of chylothorax and chylous
\end{abstract}

Atul Malhotra

atul.malhotra@monash.edu

1 Monash Newborn, Monash Children's Hospital, Clayton, VIC, Australia

2 Monash Newborn, Monash Children's Hospital, \& Department of Paediatrics, Monash University, 246 Clayton Road, Clayton, VIC, Australia ascites in neonates. However, larger prospective controlled trials are required to establish the optimal dose, time of initiation, duration and efficacy of octreotide therapy in neonates.

\section{Key Points}

Octreotide is a safe adjunct therapy for the treatment of chylothorax and chylous ascites in neonates.

The efficacy of octreotide therapy and final outcome are affected by underlying genetic conditions and associated co-morbidities.

Early initiation of octreotide therapy can be considered in the management of chylothorax and chylous ascites.

\section{Introduction}

Octreotide is a synthetic long-acting somatostatin analogue that inhibits the release of growth hormone, glucagon and insulin. It decreases pancreatic, biliary and intestinal secretions, inhibits gall bladder contraction and gastrointestinal motility, and reduces splanchnic blood flow. By virtue of these actions, octreotide can be used to reduce portal pressure, fat absorption and lymphatic flow in the thoracic duct [1,2].

It is approved for use in adults for the management of acromegaly, carcinoid tumour and vasoactive intestinal peptide tumour [3]. However, its use in the neonatal period 
is limited with evidence of its efficacy and safety being reported in case reports, case series and retrospective studies [4-6]. Systematic review of the literature showed that octreotide has been successfully used off-label in neonates for the management of congenital chylothorax, chylous ascites, pericardial effusion, congenital lymphoedema, lymphangiectasia, gastrointestinal bleeding, congenital hyperinsulinism and enterocutaneous fistula $[1,7-10]$. In addition to its anti-secretory actions, octreotide also has an anti-proliferative action, capable of stabilising tumour growth in patients with metastatic neuroendocrine malignancies, including carcinoid and pancreatic endocrine tumours [11]. Recently, long-acting somatostatin analogues (lanreotide) have been used with good results in patients with congenital hyperinsulinism and carcinoid tumours [12]. Octreotide has also been successfully used in the treatment of post-operative chylothorax after cardiothoracic surgery and congenital diaphragmatic hernia repair [4].

However, in the absence of randomised controlled trials, there are no evidence-based guidelines regarding the optimal time of initiation, dosing, duration, efficacy and safety of octreotide in neonates. Review of the literature reveals significant variation in the dosing and efficacy of octreotide treatment in neonates [1]. In this study, we share our experience of using octreotide therapy in neonates at a single tertiary-level perinatal centre.

\section{Methods}

This study is a single-centre retrospective analysis of all neonates who received octreotide therapy in our unit from January 2003 to August 2017. Our unit is a tertiary-level perinatal and neonatal surgical centre in suburban Melbourne, Australia with approximately 4000 deliveries per annum. Patients were identified using our electronic clinical database as well as the hospital pharmacy database. The study was approved as a quality assurance project by the Monash Health Human Research Ethics Committee. Individual patient data were collected from the medical records including demographic details, clinical course, interventions and any associated conditions. Information about time of initiation, route, dose, duration and adverse effects of octreotide treatment was also collated. The diagnosis of chylothorax or chylous ascites was made by analysis of the fluid with a triglyceride level more than $1.3 \mathrm{mmol} / \mathrm{L}$, protein more than $20 \mathrm{~g} / \mathrm{L}$ and/or a cell count greater than 1000 cells $/ \mu \mathrm{L}$ with a predominance of lymphocytes $(>80 \%)$. Hypoglycaemia was defined as a blood glucose level less than $2.6 \mathrm{mmol} / \mathrm{L}$ and hyperglycaemia as more than $10 \mathrm{mmol} / \mathrm{L}$. Abnormal liver function was defined as both aspartate aminotransferase and alanine aminotransferase levels twice the upper limit for normal for neonatal age. The normal thyroid-stimulating hormone level in our laboratory for neonates is $1.7-9.1 \mathrm{mU} / \mathrm{L}$. The primary outcome measured was the resolution of the chylous effusion. Resolution was considered as complete when the drainage (pleural or peritoneal) losses were less than $2 \mathrm{~mL} / \mathrm{kg} / \mathrm{day}$. The primary safety endpoint was any significant adverse drug reaction leading to discontinuation of octreotide therapy. Descriptive statistics were performed on the collected data and expressed as numbers or percentages.

\section{Results}

Eleven neonates had received octreotide treatment in the study period. The diagnoses associated with octreotide treatment in our experience were chylothorax and chylous ascites. The individual patient characteristics are summarised in Table 1. The male-to-female ratio was 1:2. The majority of the neonates were born preterm $(10 / 11,90 \%)$ with gestation ranging from 28 to 38 weeks. There were nine cases of chylothorax and two cases of chylous ascites. Three cases of chylothorax were congenital, two were idiopathic and the remaining four were secondary to diaphragmatic hernia repair (1), (superior vena cava) thrombus (1) or intercostal drainage of pneumothorax (2). There was one case of congenital, and one of postoperative (necrotising enterocolitis related) chylous ascites. The median birth weight was $2303 \mathrm{~g}$ (908-3204 g). Hydropic features were noted in three neonates. Six neonates were delivered by caesarean section and five by vaginal delivery. The median duration of stay in the hospital was 65 days (25-178 days). All the neonates had significant co-morbidities, which affected their duration of hospital stay and the final outcome. Initial management in all the cases was tube (pleural or peritoneal) drainage followed by cessation of enteral feeds and initiation of total parenteral nutrition. Subsequently, after a median duration of 16 days (4-27 days), the neonates were started on octreotide therapy because of no decrease in the tube drainage. This was followed by re-establishment of feeds using a mediumchain triglyceride-based milk formula (Monogen; Nutricia, Dublin, Ireland). The details of octreotide therapy are summarised in Table 2. Of the 11 cases, 4 (36.3\%) had complete resolution of chylous effusion on octreotide therapy. None of the neonates in our study required surgical treatment for the management of their chylous effusion. The neonates with successful resolution of chylous effusion and ascites required tube drainage for a median duration of 28 days (12-65 days). The median duration of treatment with octreotide in neonates with successful resolution was 17.5 days (7-26 days). Octreotide was administered as a continuous intravenous infusion in nine 
Table 1 Perinatal, neonatal and associated anomalies of neonates receiving octreotide therapy

\begin{tabular}{|c|c|c|c|c|c|c|c|c|}
\hline Case & Sex & $\begin{array}{l}\text { Gestation } \\
\text { (weeks) }\end{array}$ & $\begin{array}{l}\text { Birth } \\
\text { weight } \\
\text { (g) }\end{array}$ & Congenital anomalies & $\begin{array}{l}\text { Delivery } \\
\text { mode }\end{array}$ & $\begin{array}{l}\text { Total duration stay in } \\
\text { hospital (days) }\end{array}$ & $\begin{array}{l}\text { Associated } \\
\text { problems }\end{array}$ & Outcome \\
\hline 1 & M & $32+6$ & 2548 & $\begin{array}{l}\text { a. Arthrogryposis } \\
\text { b. Congenital hypotonia [X-linked } \\
\text { centronuclear myopathy] } \\
\text { c. Patent ductus arteriosus } \\
\text { d. Undescended testes [bilateral] }\end{array}$ & $\mathrm{CS}$ & 80 & $\begin{array}{l}\text { a. Bilateral } \\
\text { chylothorax } \\
\text { b. Prematurity } \\
\text { c. Infant of diabetic } \\
\text { mother } \\
\text { d. Sepsis } \\
\text { e. Cardiac } \\
\text { arrhythmias } \\
\text { f. Pneumothorax } \\
\text { g. Respiratory } \\
\text { distress } \\
\text { syndrome } \\
\text { h. Anaemia }\end{array}$ & Died \\
\hline 2 & $\mathrm{~F}$ & 28 & 1150 & $\begin{array}{l}\text { a. Myotonic dystrophy } \\
\text { b. Hypoplastic lungs } \\
\text { c. Patent ductus arteriosus }\end{array}$ & VD & 31 & $\begin{array}{l}\text { a. Bilateral } \\
\text { chylothorax } \\
\text { b. Prematurity } \\
\text { c. Pneumothorax } \\
\text { d. Hypothyroidism } \\
\text { e. Sepsis }\end{array}$ & Died \\
\hline 3 & M & $34+6$ & 1260 & $\begin{array}{l}\text { a. Dysmorphism } \\
\text { b. Undescended testes [right] } \\
\text { c. Atrial septal defect } \\
\text { d. Patent ductus arteriosus } \\
\text { d. Renal cyst } \\
\text { e. Cleft palate } \\
\text { f. Hypospadias } \\
\text { g. Optic nerve hypoplasia }\end{array}$ & CS & 98 & $\begin{array}{l}\text { a. Chylous ascites } \\
\text { b. Prematurity } \\
\text { c. Intrauterine } \\
\text { growth } \\
\text { retardation } \\
\text { d. Sepsis } \\
\text { e. Pulmonary } \\
\text { haemorrhage } \\
\text { f. Renal failure } \\
\text { g. Hepatic failure } \\
\text { h. Coagulopathy } \\
\text { i. Necrotising } \\
\text { enterocolitis } \\
\text { stage 3B }\end{array}$ & Died \\
\hline 4 & M & $28+4$ & 908 & & VD & 113 & $\begin{array}{l}\text { a. Bilateral } \\
\text { chylothorax } \\
\text { b. Prematurity } \\
\text { c. Superior vena } \\
\text { cava } \\
\text { thrombus } \\
\text { d. Retinopathy of } \\
\text { prematurity } \\
\text { e. Intraventricular } \\
\text { haemorrhage } \\
\text { f. Coxsackie } 4 \\
\text { viraemia } \\
\text { g. Persistent } \\
\text { pulmonary } \\
\text { hypertension } \\
\text { h. Sepsis }\end{array}$ & Died \\
\hline
\end{tabular}


Table 1 continued

\begin{tabular}{|c|c|c|c|c|c|c|c|c|}
\hline Case & Sex & $\begin{array}{l}\text { Gestation } \\
\text { (weeks) }\end{array}$ & $\begin{array}{l}\text { Birth } \\
\text { weight } \\
\text { (g) }\end{array}$ & Congenital anomalies & $\begin{array}{l}\text { Delivery } \\
\text { mode }\end{array}$ & $\begin{array}{l}\text { Total duration stay in } \\
\text { hospital (days) }\end{array}$ & $\begin{array}{l}\text { Associated } \\
\text { problems }\end{array}$ & Outcome \\
\hline 5 & M & $32+2$ & 2750 & $\begin{array}{l}\text { a. Congenital chylothorax } \\
\text { b. Hydrops fetalis [non-immune] } \\
\text { c. Dysmorphism } \\
\text { d. Hypertrophic cardiomyopathy }\end{array}$ & $\mathrm{CS}$ & 25 & $\begin{array}{l}\text { a. Prematurity } \\
\text { b. Sepsis } \\
\text { c. Pulmonary } \\
\text { haemorrhage }\end{array}$ & Died \\
\hline 6 & M & $38+4$ & 3204 & $\begin{array}{l}\text { a. Congenital diaphragmatic hernia } \\
\text { b. Patent ductus arteriosus }\end{array}$ & CS & 34 & $\begin{array}{l}\text { a. Left chylothorax } \\
\text { b. Sepsis } \\
\text { c. Gastroesophageal } \\
\text { reflux } \\
\text { d. Persistent } \\
\text { pulmonary } \\
\text { hypertension }\end{array}$ & Survived \\
\hline 7 & $\mathrm{~F}$ & 36 & 2303 & $\begin{array}{l}\text { a. Congenital chylothorax } \\
\text { b. PTPN11 mutation } \\
\text { c. Noonan syndrome } \\
\text { d. Juvenile myelo-monocytic } \\
\text { leukaemia } \\
\text { e. Pulmonary hypoplasia } \\
\text { f. Hydrops fetalis } \\
\text { g. Lymphangiectasia }\end{array}$ & VD & 65 & $\begin{array}{l}\text { a. Prematurity } \\
\text { b. Sepsis }\end{array}$ & Died \\
\hline 8 & $\mathrm{~F}$ & 31 & 2518 & $\begin{array}{l}\text { a. Congenital ascites } \\
\text { b. Dysmorphism } \\
\text { c. Nephrocalcinosis }\end{array}$ & VD & 59 & $\begin{array}{l}\text { a. Prematurity } \\
\text { b. Sepsis }\end{array}$ & Survived \\
\hline 9 & $\mathrm{~F}$ & 28 & 920 & a. Lymphangioma & $\mathrm{CS}$ & 178 & $\begin{array}{l}\text { a. Bilateral } \\
\text { chylothorax } \\
\text { b. Prematurity } \\
\text { c. Sepsis }\end{array}$ & Survived \\
\hline 10 & M & 28 & 1075 & $\begin{array}{l}\text { a. Umbilical hernia } \\
\text { b. Trisomy } 21\end{array}$ & VD & 129 & $\begin{array}{l}\text { a. Left chylothorax } \\
\text { b. Hyaline } \\
\text { membrane disease } \\
\text { c. Chronic lung } \\
\text { disease } \\
\text { d. Sepsis } \\
\text { e. Jaundice } \\
\text { f. Transient renal } \\
\text { tubular acidosis } \\
\text { g. Prematurity } \\
\text { h. Neutropenia } \\
\text { i. Anaemia of } \\
\text { prematurity }\end{array}$ & Survived \\
\hline 11 & $\mathrm{~F}$ & 35 & 3175 & $\begin{array}{l}\text { a. Hydrops fetalis } \\
\text { b. Trisomy } 21 \\
\text { c. Tracheobronchomalacia } \\
\text { d. Congenital hypothyroidism }\end{array}$ & CS & 33 & $\begin{array}{l}\text { a. Right } \\
\text { chylothorax } \\
\text { b. Prematurity } \\
\text { c. Chylopharyngeal } \\
\text { fistula } \\
\text { d. Acute renal } \\
\text { failure }\end{array}$ & Died \\
\hline
\end{tabular}

CS caesarean section, $F$ female, $M$ male, $V D$ vaginal delivery 


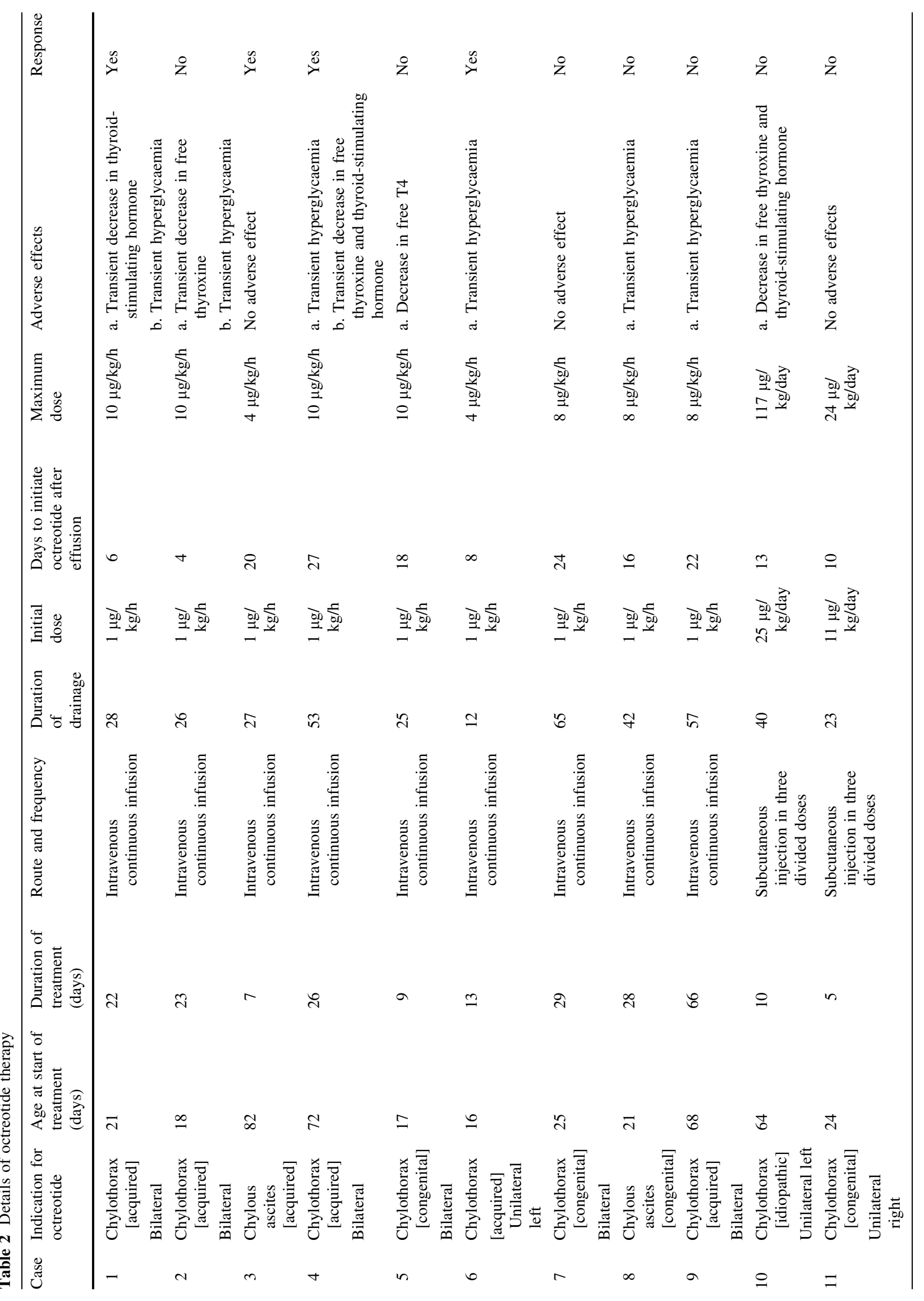


cases. The dose of continuous intravenous octreotide in our study ranged from 1 to $10 \mu \mathrm{g} / \mathrm{kg} / \mathrm{h}$. Subcutaneous octreotide $(11-117 \mu \mathrm{g} / \mathrm{kg} /$ day in three divided doses) was administered in two cases.

Use of octreotide was found to be safe and there were no significant side effects that required discontinuation of octreotide therapy. Six neonates had transient hyperglycaemia and five had transient derangement in the thyroid function tests. Overall mortality rate was $63.6 \%(7 / 11)$, with sepsis as the primary cause of death. Most of the neonates had co-morbid conditions such as X-linked centronuclear myopathy, Trisomy 21, lymphangiectasia, pulmonary hypoplasia, Noonan syndrome (PTPN11 mutation), myotonic dystrophy, chylopharyngeal fistula and juvenile myelomonocytic leukaemia. About $55 \%$ of the neonates had dysmorphic features. In 7 of the 11 neonates who died despite all interventions, octreotide was given as part of their chylothorax or chylous ascites management. None of the deaths was attributed to the adverse effects of octreotide therapy; rather, they were related to the presence of significant co-morbid conditions.

\section{Discussion}

Octreotide was used for the first time in the treatment of a neonate with congenital hyperinsulinism in 1986 and in congenital chylothorax in 2003 [2]. It is a synthetic somatostatin analogue with a longer half-life and higher potency with fewer side effects [2]. The diagnoses associated with octreotide therapy in our study were chylothorax and chylous ascites. Both these conditions are relatively rare (about 1 in 10,000) in the neonatal period with high morbidity and mortality if not treated appropriately [13]. Data supporting the efficacy of octreotide in the management of neonates with chylothorax and chylous ascites are sparse. A 2010 Cochrane review identified 19 cases of chylothorax with a wide variation in octreotide timing, dose and duration as well as inconsistent success [4]. In our study, successful resolution of chylous effusion after starting octreotide therapy was seen in 4 out of 11 neonates $(36.3 \%)$. Previous studies on octreotide therapy in chylothorax have shown variable results with variable success rates $[5,6]$. In a study conducted by Caverly et al., 12 out of 19 patients $(63 \%)$ with congenital heart disease who developed postoperative chylothorax responded to octreotide treatment [14]. A Cochrane review on the role of octreotide in neonates found 14 out of 19 cases $(73.6 \%)$ had successful resolution of chylothorax after octreotide treatment [4]. On the contrary, Church et al. in their study on neonates with chylothorax found no additional advantage of octreotide over total parenteral nutrition [15]. In our study, the aetiology of chylous effusion was heterogeneous and the associated co-morbid conditions could be a confounding factor contributing to the low success rate.

The duration of octreotide therapy in our study ranged from 7 to 66 days. However, when the data were stratified based on octreotide responders, the duration ranged from 7 to 26 days with a median of 17.5 days. In a study conducted by Aljazairi et al., the duration of administration of octreotide ranged from 5 to 15 days [5]. Similar results have been reported in other studies where the duration of octreotide therapy in cases of successful resolution varied between 5 and 25 days [2, 10, 16, 17]. Thus, octreotide therapy has been reported to result in faster resolution of chylous effusion as compared with only conventional therapy. Conventional regimens usually require longer treatment duration, resulting in prolonged leakage of chyle leading to malnutrition, infections and prolonged hospital stay. Octreotide therapy was initiated in our study when initial conservative measures such as total parenteral nutrition failed to resolve the chylous effusion. The median time of initiation of octreotide therapy after diagnosis of chylous effusion was 16 days (4-27 days). Goyal et al. and Jarir et al. started octreotide therapy on the ninth and the tenth day of the chylous effusion, respectively [16, 17]. Moreira-Pinto et al. started octreotide on the second day of chylous effusion resulting in faster resolution [10]. Given these promising data, prospective controlled trials should be considered in the future for early initiation of octreotide therapy.

Octreotide has been used either subcutaneously (10-70 $\mu \mathrm{g} / \mathrm{kg} /$ day) or intravenously as a continuous infusion $(0.3-10 \mu \mathrm{g} / \mathrm{kg} / \mathrm{h})$ in various studies $[5,6,10,16$, 18-20]. We used octreotide as a continuous intravenous infusion and the subcutaneous route in doses that were similar to previously published octreotide dosing regimens. The subcutaneous route was preferred before 2004 as per our local hospital pharmacy guidelines. However, after 2004, continuous intravenous infusion has been used for octreotide administration. Harris et al. in their study on patients with acromegaly found less serious adverse effects of octreotide and better symptom control when it was used as a continuous infusion as compared with an intermittent subcutaneous injection [21]. As a continuous infusion, octreotide was started at a rate of $1 \mu \mathrm{g} / \mathrm{kg} / \mathrm{h}$, which was gradually increased by $1 \mu \mathrm{g} / \mathrm{kg}$ daily depending upon the response till a maximum dose of $10 \mu \mathrm{g} / \mathrm{kg} / \mathrm{h}$ was reached. This is similar to most studies where the treatment was started with a lower dose and progressively increased, but the dose to elicit a significant reduction in chylous effusion was quite variable $[2,5,10,16,17]$. The maximum dose required for successful resolution in our study was $4-10 \mu \mathrm{g} / \mathrm{kg} / \mathrm{h}$ with a median of $8 \mu \mathrm{g} / \mathrm{kg} / \mathrm{h}$. The maximum dose of octreotide reported in several studies in neonates is $10 \mu \mathrm{g} / \mathrm{kg} / \mathrm{h}[4,5,10,16]$. In our cases with successful 
resolution, the chylous effusion resolved within 3-16 days of reaching the maximum dose of octreotide infusion. Similar results were seen in the studies done by Jarir et al. and Paget-Brown et al. where the chylous effusion resolved between 2 and 8 days of reaching the maximum dose of octreotide infusion $[17,18]$.

Although there is still uncertainty regarding the initiating dose, our experience suggests that starting at a higher dose may yield a better and faster outcome. There is no consensus in the literature about how long octreotide therapy should be continued or the method of weaning of octreotide infusion after resolution of chylous effusion. We abruptly ceased octreotide infusion within $48 \mathrm{~h}$ of successful resolution of chylous effusion without any recurrence. On the contrary, Jarir et al. and Shah and Sinn carried out a gradual weaning of the octreotide infusion over 3-5 days after resolution of the chylous effusion $[2,17]$. In both studies, there were no side effects or recurrence of chylous effusion reported. There is no consensus in the literature about the initiation of enteral feeding while receiving octreotide therapy. We started enteral feeds (monogen) a few days after initiation of the octreotide infusion. In some studies, patients were receiving total parenteral nutrition until the resolution of chylothorax, whereas in other studies, enteral feeds were stated at the time of initiation of octreotide therapy [10]. The associated co-morbidities can cause delay in the initiation of enteral feeds as seen in our study. The neonates with successful resolution of chylous effusion required tube drainage for a median duration of 28 days (12-65 days). This is similar to other studies where the median duration of chest tube drainage was 12.5 days (2-51 days) [19].

Both hypo- and hyperglycaemia are expected adverse effects as a result of octreotide action on the insulin/glucagon balance [1]. Octreotide is also known to cause suppression of the thyroid-stimulating hormone at the hypothalamus/pituitary level [22]. The adverse effects noted in our study were transient hyperglycaemia and deranged thyroid function tests. These could be related to octreotide therapy or the underlying disease or concomitant medications. These adverse effects can be considered as a 'possible' adverse reaction as per the causality assessment with the Naranjo's Adverse Drug Reactions Probability Scale [23]. Flatulence, transient elevation of liver enzymes, arrhythmias, diarrhoea, hypotension, necrotising enterocolitis, renal impairment and cholelithiasis are some of the other side effects reported [1,2]. Arevalo et al. reported that octreotide may lead to hypoxemia and pulmonary hypertension in preterm neonates [24]. Church et al. in their study found a higher risk of necrotising enterocolitis $(30 \%)$ in preterm babies ( $<36$ weeks) who received octreotide therapy as compared with those who were managed with only total parenteral nutrition [15]. None of the neonates in our study developed a significant side effect that required permanent discontinuation of octreotide therapy. Similar safety profiles have been documented by Testoni et al. and Shah et al. in their studies [1, 2, 25]. Although mortality was high in our study, none of the deaths were attributed to the adverse effects of octreotide therapy. All the deaths were related to the presence of genetic and significant co-morbid conditions. The strengths of our study include a relatively larger sample size and a longer duration of study as compared with previous studies. We could collect and analyse information on a daily basis for all neonates receiving octreotide therapy in our database. Information on concomitant diagnosis and adverse effects of octreotide therapy was also simultaneously analysed. However, its retrospective nature, lack of followup and inclusion of patients from only a single centre limited our study. Other limitations were the lack of controls owing to the relative rarity of the condition. In addition, the presence of associated genetic and co-morbid conditions probably had a confounding effect on the efficacy of octreotide therapy.

\section{Conclusion}

We found that complete resolution of chylous effusion after starting octreotide therapy was seen in $36.3 \%$ of cases. As neonates were also receiving total parenteral nutrition, it is difficult to attribute the resolution of chylous effusion exclusively to octreotide therapy. As there were no significant side effects, octreotide appears to be relatively safe drug to administer. However, it is difficult to draw a final conclusion on drug safety from a small retrospective study and hence adverse effects still need to be monitored. The underlying genetic and associated co-morbid conditions can affect the efficacy of octreotide therapy and the final outcome. Larger prospective controlled trials should be considered in the future to establish optimal initial dosing, time of initiation, duration, safety and efficacy of octreotide treatment in neonates.

\section{Compliance with Ethical Standards}

Funding No sources of funding were received for the preparation of this article.

Conflict of Interest Syed Ahmed Zaki, Mohan B. Krishnamurthy and Atul Malhotra have no conflicts of interest directly relevant to the content of this article.

Authors Contributions SAZ collected and analysed the data and wrote the first draft of the manuscript. MBK reviewed the manuscript. AM conceived the study idea, supervised the writing of the manuscript and critically revised the manuscript. 
Ethics Approval The study was approved by the Monash Health Human Research Ethics Committee.

Open Access This article is distributed under the terms of the Creative Commons Attribution-NonCommercial 4.0 International License (http://creativecommons.org/licenses/by-nc/4.0/), which permits any noncommercial use, distribution, and reproduction in any medium, provided you give appropriate credit to the original author(s) and the source, provide a link to the Creative Commons license, and indicate if changes were made.

\section{References}

1. Testoni D, Hornik CP, Neely ML, Yang Q, McMahon AW, Clark RH, Smith PB, Best Pharmaceuticals for Children Act-Pediatrics Trial Network Administrative Core Committee. Safety of octreotide in hospitalized infants. Early Hum Dev. 2015;91:387-92.

2. Shah D, Sinn JK. Octreotide as a therapeutic option for congenital idiopathic chylothorax: a case series. Acta Paediatr. 2012;101:e151-5.

3. US Food and Drug Administration. Sandostatin (octreotide acetate) injection. http://www.accessdata.fda.gov/drugsatfda docs/label/2012/019667s061lbl.pdf. Accessed 8 Aug 2017.

4. Das A, Shah PS. Octreotide for the treatment of chylothorax in neonates. Cochrane Database Syst Rev. 2010;9:CD006388.

5. Aljazairi AS, Bhuiyan TA, Alwadai AH, Almehizia RA. Octreotide use in post-cardiac surgery chylothorax: a 12 year perspective. Asian Cardiovasc Thorac Ann. 2017;25:6-12.

6. Landis MW, Butler D, Lim FY, Keswani S, Frischer J, Haberman B, Kingma PS. Octreotide for chylous effusion in congenital diaphragmatic hernia. J Pediatr Surg. 2013;48:2226-9.

7. McMohan AW, Wharton GT, Thornton P, De Leon DD. Octreotide use and safety in infants with hyperinsulinism. Pharmacoepidemiol Drug Saf. 2017;26:26-31.

8. Al Sinani S, Rawahi YA, Abdoon H. Octreotide in Hennekam syndrome associated intestinal lymphangiectasia. World J Gastroenetrol. 2012;18:6333-7.

9. Downie L, Sasi A, Malhotra A. Congenital chylothorax: association and neonatal outcomes. J Paediatr Child Health. 2014;50:234-8.

10. Moreira-Pinto J, Rocha P, Osorio A, Bonet B, Carvalho F, Duarte $\mathrm{C}$, Oliveira L. Octreotide in the treatment of neonatal postoperative chylothorax: report of three cases and literature review. Pediatr Surg Int. 2011;27:805-9.

11. Van der Steen I, van Albada ME, Mohnike K, Christesen HT, Empting S, Salomon-Estebanez M, Greve Rasmussen A, Verrijn Stuart A, van der Linde AAA, Banerjee I, Boot AM. A multicenter experience with long-acting somatostatin analogues in patients with congenital hyperinsulinism. Horm Res Paediatr. 2018;89:82-9.

12. Sidéris L, Dubé P, Rinke A. Antitumor effects of somatostatin analogs in neuroendocrine tumors. Oncologist. 2012;17:747-55.

13. Bellini C, Ergaz Z, Radicioni M, Forner-Cordero I, Witte M, Perotti G, et al. Congenital fetal and neonatal visceral chylous effusions: neonatal chylothorax and chylous ascites revisited. A multicentre retrospective study. Lymphology. 2012;45:91-102.

14. Caverly L, Rausch CM, da Cruz E, Kaufman J. Octreotide treatment of chylothorax in pediatric patients following cardiothoracic surgery. Congenit Heart Dis. 2010;5:573-8.

15. Church JT, Antunez AG, Dean A, Matusko N, Deatrick KB, Attar MA, Gadepalli SK. Evidence based management of chylothorax in infants. J Pediatr Surg. 2017;52:907-12.

16. Goyal A, Smith NP, Jesudason EC, Kerr S, Losty PD. Octreotide for treatment of chylothorax after repair of congenital diaphragmatic hernia. J Pediatr Surg. 2003;38:E19-20.

17. Jarir RA, Rahman SU, Bassiounylel S. Use of octreotide in the management of neonatal chylothorax secondary to repair of congenital diaphragmatic hernia: a report of two cases and review of literature. J Clin Neonatol. 2012;1:91-5.

18. Paget-Brown A, Kattwinkel J, Rodgers BM, Micchalsky MP. The use of octreotide to treat congenital chylothorax. J Pediatr Surg. 2006;41:854-7.

19. Yin R, Zhang R, Wang J, Yuan L, Hu L, Jiang S, Chen C, Cao Y. Effects of somatostatin/octreotide treatment in neonates with congenital chylothorax. Medicine (Baltim). 2017;96:e7594.

20. Young S, Dalgleish S, Eccleston A, Akierman A, McMillan D. Severe congenital chylothorax treated with octreotide. J Perinatol. 2004;24:200-2.

21. Harris AG, Kokoris SP, Ezzat S. Continous versus intermittent subcutaneous infusion of octreotide in the treatment of acromegaly. J Clin Pharmacol. 1995;35:59-71.

22. Haugen BR. Drugs that suppress TSH or cause central hypothyroidism. Best Pract Res Clin Endocrinol Metab. 2009;23:793-800.

23. Naranjo CA, Busto U, Sellers EM, Sandor P, Roberts I, Ruiz A, et al. A method for estimating the probability of adverse drug reactions. Clin Pharmacol Ther. 1981;30:239-45.

24. Arevalo RP, Bullabh P, Krauss AN, Auld PA, Spigland N. Octreotide-induced hypoxemia and pulmonary hypertension in premature neonates. J Pediatr Surg. 2003;38:251-3.

25. Bellini C, Cabano R, De Angelis LC, Bellini T, Calevo MG, Gandullia P, Ramenghi LA. Octreotide for congenital and acquired chylothorax in newborns: a systematic review. J Paediatr Child Health. 2018. https://doi.org/10.1111/jpc.13889 (Epub ahead of print). 